УДК 351

https://doi.org/10.32689/2708-7530-2020-1(1)-40-49

Жукова Ірина Віталіївна кандидат наук з державного управління, доцент, Заступник директора 3 навчально-виховної роботи Навчально-наукового інституту менеджменту та психології ДЗВО «Університет менеджменту освіти» НАПН України, Україна, м. Київ, вул. Січових стрільців, 52-А, тел.: 063 95178 55, e-mail: irina_pravo@ukr.net, https//orcid.org/0000-0003-4927-0610

Мурашко Віталій Сергійович старший викладач кафедри публічного адміністрування, аспірант Міжрегіональної Академії управління персоналом, 03039, м. Київ, вул. Фрометівська, 2, тел.: 06349531 43, e-mail: murashko.vitalii1981@gmail.com, https//orcid.org/0000-0002-8668-2043

\title{
НАПРЯМИ ПІДВИЩЕННЯ ЕФЕКТИВНОСТІ ІНФОРМАЦЙНО- АНАЛІТИЧНОГО ТА РЕСУРСНОГО ЗАБЕЗПЕЧЕННЯ ФУНКЦІОНУВАННЯ МЕХАНІЗМІВ ЗАБЕЗПЕЧЕННЯ НАЦІОНАЛЬНОӤ БЕЗПЕКИ УКРАЇНИ У КОНТЕКСТІ ЄВРОПЕЙСЬКОГО ДОСВІДУ
}

Анотація: У статті проаналізовано розвиток напрямів підвищення ефективності інформаційно-аналітичного та ресурсного забезпечення функціонування механізмів забезпечення національної безпеки України у контексті європейського досвіду. Визначено, що за належне функціонування інформаційно-аналітичного забезпечення органів військової адміністрації відповідають різні структурні підрозділи та підпорядковані їм експерти. Наприклад, Управління комунікацій і преси Міністерства оборони України та Управління зв'язків 3 громадськістю Збройних сил України займаються аналізом, прогнозуванням, розробкою стратегічних, ситуаційно-сценаріальних пропозицій та рекомендацій для реалізації велико-масштабних рішень щодо діяльності Міністерства оборони України та Генерального штабу Збройних сил України та їх висвітленням у засобах масової інформації.

Паралельно досліджено, що управління комунікацій та преси Міністерства оборони України є структурним підрозділом апарату Міністерства оборони України, призначеним для реалізації державної інформаційної політики в Міністерстві оборони та Збройних силах України щодо виконання інформаційних завдань, забезпечення ефективного функціонування інформаційної системи взаємодії з громадськістю та зі ЗМІ. 
Акцентовано на тому, що згідно з затвердженою схемою прийняття та реалізації адміністративних рішень, спочатку, відбувається процес оцінювання їх наявного стану та виявлення прогнозованих аспектів їх упровадження, потім - вироблення сценарію їх реалізації, а вже після цього - контроль за їх виконанням. У контексті інформаційно-аналітичного забезпечення, оцінка стану та прогнозування, а, також, прийняття рішення - це конкретні етапи адміністрування, яким приділено набагато більше уваги, аніж впровадженню у життя самого рішення у напрямі його інформаційно-аналітичного забезпечення. Саме тому, важливо окреслити проблеми цього етапу i знайти шляхи їх вирішення.

У процесі прийняття та реалізації адміністративних рішень виявлено проблеми оптимізаційного спрямування, такі як: відсутність скоординованих інформаційних потоків, які направлені на забезпечення процесу впровадження у життя рішень, які будуть оптимальні за просторово-часовими конфігураціями.

Ключові слова: механізми державного управління, інформаційноаналітичне забезпечення, прийняття управлінських рішень, функціонування механізмів національної безпеки, програмно-апаратне забезпечення органів військового управління.

Zhukova Iryna Vitaliivna Candidate of Sciences in Public Administration, Associate Professor, Deputy Director for Educational Work of the Educational and Scientific Institute of Management and Psychology of the State Educational Institution "University of Education Management" of the National Academy of Pedagogical Sciences of Ukraine, Ukraine, Kyiv, str. Sichovykh Striltsiv, 52-A, tel.: 06395178 55, e-mail: irina_pravo@ukr.net, https//orcid.org/0000-0003-4927-0610

Murashko Vitaliy Sergeevich, Senior Lecturer of the Department of Public Administration, Postgraduate of Interregional Academy of Personnel Management, 03039, Kiev, st. Frometovskaya, 2, tel.: 06349531 43, e-mail: murashko.vitalii1981@gmail.com, https//orcid.org/0000-0002-8668-2043

\section{DIRECTIONS OF IMPROVING THE EFFICIENCY OF INFORMATION- ANALYTICAL AND RESOURCE SUPPORT FUNCTIONING OF MECHANISMS FOR SECURING}

\footnotetext{
Abstract: The article analyzes the development of ways to increase the efficiency of information-analytical and resource provision of the functioning of mechanisms for ensuring
} 
the national security of Ukraine in the context of European experience. It is determined that various structural subdivisions and subordinate experts are responsible for the proper functioning of information and analytical support of military administration bodies. For example, the Communications and Press Department of the Ministry of Defense of Ukraine and the Public Relations Department of the Armed Forces of Ukraine analyze, forecast, develop strategic, situational and scenario proposals and recommendations for large-scale decisions on the Ministry of Defense of Ukraine and the General Staff of the Armed Forces of Ukraine. and their coverage in the media.

In parallel, it was investigated that the Department of Communications and Press of the Ministry of Defense of Ukraine is a structural unit of the Ministry of Defense of Ukraine, designed to implement state information policy in the Ministry of Defense and the Armed Forces of Ukraine to perform information tasks, ensure effective functioning of information system.

It is emphasized that according to the approved scheme of making and implementing administrative decisions, first, there is a process of assessing their status and identifying projected aspects of their implementation, then developing a scenario for their implementation, and only then - monitoring their implementation. In the context of information-analytical support, condition assessment and forecasting, as well as decision-making are specific stages of administration, which are given much more attention than the implementation of the decision in the direction of its information-analytical support. That is why it is important to outline the problems of this stage and find ways to solve them.

In the process of making and implementing administrative decisions, optimization problems were identified, such as: the lack of coordinated information flows, which are aimed at ensuring the implementation of decisions that will be optimal for space-time configurations.

Keywords: mechanisms of public administration, information and analytical support, management decisions, functioning of national security mechanisms, software and hardware of military administration.

Постановка проблеми. Існування, самозбереження та прогресивний розвиток України як суверенної держави залежать від проведення органами влади цілеспрямованої політики щодо прийняття своєчасних i адекватних рішень щодо нейтралізації виявлених загроз і ризиків сфері національної безпеки України. При цьому, важливо, щоб національні інтереси України безпеки України. При цьому, важливо, щоб національні інтереси України відображали основні цінності та засадничі прагнення громадян, їхні потреби 
у забезпеченні гідних умов життя, а, також, цивілізовані способи їх реалізації.

Національна безпека України як стан захисту життєвих інтересів людини, суспільства та держави від внутрішніх і зовнішніх загроз є необхідною умовою збереження та примноження матеріальних та духовних цінностей нашої держави [1, с. 536]. За останні кілька років, відбулося багато змін через регіональні та глобальні тенденції розвитку різних сфер життєдіяльності суспільства і держави, які безпосередньо впливають на ситуацію в Україні. Глобальний та регіональний контекст національної безпеки України, сьогодні, змінюється, як ніколи, i значна частина глобальних загроз, які були неактуальними для України кілька років тому, стали реальністю нашого сьогодення [2, с. 426].

Аналіз останніх досліджень та публікацій. Вивчення інформаційноаналітичного та ресурсного забезпечення функціонування механізмів забезпечення національної безпеки України здійснювали Антонов В. О., Моргалюк О. В., Пугач А. О., Рубан А. В. та ін. Проте, навіть за наявності таких досліджень, заходи щодо реалізації інформаційно-аналітичної діяльності у сфері оборони з урахуванням євроатлантичного курсу нашої країни потребують вивчення.

Метою статті $є$ дослідити розвиток напрямів підвищення ефективності інформаційно-аналітичного та ресурсного забезпечення функціонування механізмів забезпечення національної безпеки України у контексті європейського досвіду.

Виклад основного матеріалу. Існування сучасної держави неможливе без розвиненої системи державного управління, що характеризується стрімким потоком нововведень, наслідки яких далеко не завжди позитивні. Тому, загострюється потреба у створенні надійної системи інформаційноаналітичного забезпечення державного управління національною безпекою [3].

Державна політика України у сфері національної оборони повинна бути орієнтована на вдосконалення Збройних сил України, інших військ, а, також, військових формувань та органів, покликаних забезпечити безпеку, суверенітет та територіальну цілісність держави при будь-яких умовах розгортання військово-політичної ситуації у країні.

Україна реалізує державну політику у сфері національної оборони шляхом розробки системи основних концептуальних, програмних документів, а, також, норм законодавчого регулювання діяльності органів державної влади, установ, підприємств та організацій реального сектору економіки, інститутів громадянського суспільства у мирний та воєнний часи, а, також, через вдосконалення сил та засобів цивільної оборони, мереж транспортної 
інфраструктури тощо [4, с. 166].

За належне функціонування інформаційно-аналітичного забезпечення органів військової адміністрації відповідають різні структурні підрозділи та підпорядковані їм експерти. Наприклад, Управління комунікацій і преси Міністерства оборони України та Управління зв'язків 3 громадськістю Збройних сил України займаються аналізом, прогнозуванням, розробкою стратегічних, ситуаційно-сценаріальних пропозицій та рекомендацій для реалізації велико-масштабних рішень щодо діяльності Міністерства оборони України та Генерального штабу Збройних сил України та їх висвітленням у засобах масової інформації [5, с. 12].

Управління комунікацій та преси Міністерства оборони України є структурним підрозділом апарату Міністерства оборони України, призначеним для реалізації державної інформаційної політики в Міністерстві оборони та Збройних силах України щодо виконання інформаційних завдань, забезпечення ефективного функціонування інформаційної системи взаємодії з громадськістю та зі 3MI [6].

Іншим органом, який повинен підтримувати національну безпеку, $\epsilon$ Державна служба спеціального зв'язку та інформації, яка забезпечує інформаційну безпеку та зв’язок для органів державної влади, реалізує їх інформаційно-аналітичну підтримку, технічне обслуговування та програмне забезпечення, a, також, сприяє розробці інформаційно-телекомунікаційних систем та ситуаційних центрів для управління державою у воєнний час та в надзвичайних ситуаціях.

\section{Серед сучасних напрямів розвитку установи визначимо наступні:}

- ведення зовнішньої розвідки у сфері зашифрованих та інших видів спеціальних комунікацій за допомогою інноваційних засобів зв'язку для запровадження додаткових стабілізаційних заходів забезпечення національної безпеки держави;

- забезпечення вищих державних органів надійною зовнішньою розвідувальною інформацією на випередження (інформацією про стан розвитку Збройних сил, економіки в особливий період та воєнний час, про соціальноекономічний моніторинг тощо) необхідною для прийняття рішень у галузінаціональної безпеки, оборони, економіки, науки та техніки, міжнародних відносин, екології та мобілізаційної готовності [7].

Відзначимо, що, згідно з Указом Президента України [8], було прийняте рішення організувати Головний ситуаційний центр України (далі Центр) як програмно-апаратну систему для збору, акумулювання та обробки інформації, яка потрібна для опрацювання та прийняття управлінських рішень у галузі 
національної безпеки й оборони.

Центр створений 3 метою забезпечення інформаційно-аналітичного супроводу рішень Ради національної безпеки і оборони України у процесі координування та контролю діяльності державно-владних органів, правоохоронних та військових структур у галузі національної безпеки i оборони. Універсальністю цього супроводу стало те, що він реалізуються у різні періоди життєдіяльності та розвитку держави: у мирний час, в особливий період, у тому числі, в умовах воєнного стану, в умовах надзвичайного стану та у разі появи обставин кризового характеру, які, в свою чергу, загрожують національній безпеці України.

Центр повинен отримувати інформацію, зокрема, з обмеженим доступом, потрібну для його нормального та ефективного функціонувань, в тому числі, у режимі віддаленого доступу. Процес оперативної передачі інформації в установленому нормативними документами порядку має забезпечувати належне функціонування структур сектору безпеки й оборони. Варто зазначити, що, на сьогоднішній день, структури Сектору, такі як ситуаційні центри, не реалізують свою діяльність у повному об’ємі, або зовсім відсутні, а це негативно впливає на результативність роботи Центру. Хоча, наразі, триває безперервний процес запровадження комплексу програм по стратегічним комунікаціям, в тому числі, й у відповідних органах Сектору.

Для вирішення даної проблеми, прослідкувавши за роботою у галузі національної безпеки й оборони у країнах $\mathrm{CC}$, можна надати певні рекомендації щодо посилення практичних аспектів наукового супроводу процесів запровадження програм із удосконалення реалізації завдань Міністерства оборони України.

На нашу думку, належний рівень організації наукових досліджень та велика кількість дослідницьких напрацювань у цій галузі мають дати свої «плоди». Сьогодні, потрібно посилити кількість розробок, направлених на структурну оптимізацію та покращення системи адміністрування Збройними силами України, функціональне вдосконалення адміністративно-штатної побудови органів військового управління, оновлення існуючих та появу новітніх засобів зв’язку та автоматизації, що дасть змогу своєчасно виявляти, ідентифікувати загрози національній безпеці, прогнозувати їх розвиток [9, с. $83]$.

Держави, які є членами Свропейського Союзу, проблематику національної безпеки, питання щодо затвердження бюджету у цій галузі та звіти стосовно нинішнього стану оборони висвітлюють у інформаційно-аналітичних документах, які спеціально для цього опрацьовуються та готуються. Такі 
документи повинні бути затверджені державним парламентом та урядом, для того, щоб оприлюднити інформацію для широкої громадськості. Сама по собі дана інформаційна документація розробляється на основі вагомих науковоконцептуальних досліджень та результатів консультацій експертів у різних секторах оборонної галузі.

У контексті розвитку України, актуальною є проблематика розробки практико-орієнтованих державно-адміністративних моделей управління, за допомогою яких можна забезпечити належний рівень окресленння проблем політики у сфері безпеки, а, також, продукування громадської думки з даного питання [7, с. 349; 10].

Через застосування застарілих інформаційних технологій, що негативно позначається на процесах аналітичного дослідження інформаційного матеріалу, маємо визначити необхідні напрями оптимізації комплексу власних інформаційних розробок для досягнення більшої ефективності роботи механізмів забезпечення національної безпеки, серед яких:

- випереджувальне оволодіння сучасними методами аналітичних досліджень та їх зіставлення з існуючими, на даний час, технологіями;

- орієнтація на «обробку» знань (сутності інформаціі), а не тексту (конфігурації інформації);

- направлення на всебічну автоматизацію будь-яких етапів процесу оцінювання інформації.

Захист інформаційно-аналітичного забезпечення органів державного i військового адмініструвань національної безпеки, на нашу думку, повинен включати інноваційні методи його впровадження, а саме:

- зменшення обсягів інформаційних потоків за допомогою їх узагальнення з урахуванням потреб щодо їх цілісності;

- об’єктивне оцінювання інформації щодо іiі повноти та комплексності;

- визначення суперечливої інформації, а, також, процесів дезінформації.

Висновки. Констатовано той факт, що системи інформаційноаналітичного забезпечення повинні, в першу чергу, задовольняти вимоги, які висуваються до завдань, які вирішуються структурами адміністрування на всіх етапах регулювання роботи механізмів забезпечення національної безпеки.

Згідно з затвердженою схемою прийняття та реалізації адміністративних рішень, спочатку, відбувається процес оцінювання їх наявного стану та виявлення прогнозованих аспектів їх упровадження, потім - вироблення сценарію їх реалізації, а вже після цього - контроль за їх виконанням. У контексті інформаційно-аналітичного забезпечення, оцінка стану та прогнозування, a, також, прийняття рішення - це конкретні етапи 
адміністрування, яким приділено набагато більше уваги, аніж впровадженню у життя самого рішення у напрямі його інформаційно-аналітичного забезпечення. Саме тому, важливо окреслити проблеми цього етапу i знайти шляхи їх вирішення.

У процесі прийняття та реалізації адміністративних рішень нами виявлено проблеми оптимізаційного спрямування, такі як: відсутність скоординованих інформаційних потоків, які направлені на забезпечення процесу впровадження у життя рішень, які будуть оптимальні за просторово-часовими конфігураціями.

\section{Лimepamypa:}

1. Антонов В. О. Конституційно-правові засади національної безпеки України: монографія / В. О. Антонов; наук. ред. Ю.С. Шемшученко. Київ: ТАЛКОМ, 2017. С.576 .

2. Моргалюк О. В. Проблема забезпечення національної безпеки в умовах глобалізації / О. В. Моргалюк // Свропейська інтеграція в контексті сучасної геополітики : зб. наук. статей за матеріалами наук. конф., м. Харків, 24 трав. 2016 р. / редкол.: А. П. Гетьман, І. В. Яковюк, В. І. Самощенко та ін. - Х. : Право, 2016. - С. 425-428.

3. Пугач А. О. Оптимізація постановки цілей та вироблення завдань у системі інформаційно-аналітичного забезпечення державного управління України / А. О. Пугач. // Державне управління: удосконалення та розвиток. - 2012. - № 8. C.4 - Режим доступу: http:// nbuv.gov.ua/UJRN/Duur_2012_8_9

4. Рубан А. В. Державне управління у сфері національної безпеки України. Дисертація на здобуття наукового ступеня кандидата наук 3 державного управління за спеціальністю 25.00.02 - державне управління у сфері державної безпеки та охорони громадського порядку. Національний університет цивільного захисту України, Харків, 2019. C.256.

5. Роман Бакуменко / ІНФОРМАЦІЙНО-АНАЛІТИЧНЕ ЗАБЕЗПЕЧЕННЯ ОРГАНІВ ВІЙСЬКОВОГО УПРАВЛІННЯ: СТАН, ПРОБЛЕМИ ТА ПІДГОТОВКА ФАХІВЦІВ Національний університет оборони України імені Івана Черняховського ВІЙСЬКОВА ОСВІТА Збірник наукових праць Національного університету оборони України № 1 (39) 2019, С. 8-16. http://znp-vo.nuou.org.ua/article/view/176001/178684

6. Джерело: Сайт МО / Управління комунікацій та преси Міністерства оборони України http://www.mil.gov.ua/ministry/struktura-aparatu-ministerstva/upimou.html

7. Крук C.I. Інституційний розвиток державного управління у сфері забезпечення національної безпеки України - Дисертація на здобуття наукового ступеня доктора наук 3 державного управління за спеціальністю 25.00.05 - державне управління у сфері державної безпеки та охорони громадського порядку. - Національний університет цивільного захисту України. - Харків, 2019. С.449

8. Указ Президента України Про рішення Ради національної безпеки і оборони України від 2 вересня 2015 року «Про нову редакцію Воєнної доктрини України» Документ 555/2015, чинний, поточна редакція - Прийняття від 24.09.2015 http://zakon4.rada.gov.ua/laws/ show/555/2015.

9. Капштик О.В. Державні механізми стратегічних комунікацій у секторі безпеки і оборони України. Дисертація на здобуття наукового ступеня кандидата наук 3 державного управління за спеціальністю 25.00.05 “Державне управління у сфері державної безпеки та охорони громадського порядку”. - Хмельницький університет управління та права, Хмельницький, 2019. С.197. 
10. Романенко Є. О. Система маркетингових комунікацій в механізмах державного управління / С. О. Романенко, І. В. Чаплай // Актуальні проблеми економіки. 2016. - № 4. -C. 69-78.

\section{References:}

1. Antonov, V. O. (2017). Konstytutsiino-pravovi zasady natsionalnoi bezpeky Ukrainy [Constitutional and legal principles of national security of Ukraine]. Yu.S. Shemshuchenko (Eds.). Kyiv: TALKOM [in Ukrainian].

2. Morhaliuk, O. V. (2016). Problema zabezpechennia natsionalnoi bezpeky v umovakh hlobalizatsii [The problem of ensuring national security in the context of globalization]. A. P. Hetman, I. V. Yakoviuk, V. I. Samoshchenko, et al. (Eds.). Yevropeiska intehratsiia v konteksti suchasnoi heopolityky - European integration in the context of modern geopolitics : Proceedings of scientific conference. (pp. 425-428). Kharkiv: Pravo [in Ukrainian].

3. Puhach, A. O. (2012). Optymizatsiia postanovky tsilei ta vyroblennia zavdan u systemi informatsiino-analitychnoho zabezpechennia derzhavnoho upravlinnia Ukrainy [Optimization of goal setting and task development in the system of information-analytical support of public administration of Ukraine]. Derzhavne upravlinnia: udoskonalennia ta rozvytok - Public administration: improvement and development, $8 . \quad$ Retrieved from http://nbuv.gov.ua/UJRN/Duur_2012_8_9 [in Ukrainian].

4. Ruban, A. V. (2019). Derzhavne upravlinnia u sferi natsionalnoi bezpeky Ukrainy [Public administration in the field of national security of Ukraine]. Candidate's thesis. Kharkiv: Natsionalnyi universytet tsyvilnoho zakhystu Ukrainy [in Ukrainian].

5. Bakumenko, R. (2019). Informatsiino-analitychne zabezpechennia orhaniv viiskovoho upravlinnia: stan, problemy ta pidhotovka fakhivtsiv [Information and analytical support of military administration bodies: state, problems and training of specialists]. Zbirnyk naukovykh prats Natsionalnoho universytetu oborony Ukrainy - Collection of scientific works of The National Defence University of Ukraine, 1(39), 8-16. Retrieved from http://znpvo.nuou.org.ua/article/view/176001/178684 [in Ukrainian].

6. Upravlinnia komunikatsii ta presy Ministerstva oborony Ukrainy [Department of Communications and Press of the Ministry of Defense of Ukraine]. www.mil.gov.ua. https://www.mil.gov.ua/news/2020/01/24/upimou-prosit-zmi-aktualizuvati-svoi-adresi-dlya-rozsilkimaterialiv-ta-anonsiv/ [in Ukrainian].

7. Kruk, S. I. (2019). Instytutsiinyi rozvytok derzhavnoho upravlinnia u sferi zabezpechennia natsionalnoi bezpeky Ukrainy [Institutional development of public administration in the field of national security of Ukraine]. Doctor's thesis. Kharkiv: Natsionalnyi universytet tsyvilnoho zakhystu Ukrainy [in Ukrainian].

8. Ukaz Prezydenta Ukrainy "Pro rishenniaRady natsionalnobezpeky i oborony Ukrainy vid 2 veresnia 2015 roku «Pro novu redaktsiiuVoiennoidoktryny Ukrainy»": vid24.09.2015, № 555/2015 [Decree of the President of Ukraine On the decision of the National Security and Defense Council of Ukraine of September 2, 2015 "On the new version of the Military Doctrine of Ukraine" from 24.09.2015, № 555/2015]. zakon.rada.gov.ua. Retrieved from http://zakon4.rada.gov.ua/laws/ show/555/2015 [in Ukrainian].

9. Kapshtyk, O.V. (2019). Derzhavni mekhanizmy stratehichnykh komunikatsii u sektori bezpeky i oborony Ukrainy [State mechanisms of strategic communications in the security and defense sector of Ukraine]. Candidate's thesis. Khmelnytskyi: Khmelnytskyi universytet upravlinnia ta prava [in Ukrainian]. 
10. Romanenko Ye.O., Chaplay I.V. (2016) System of marketing communications in mechanisms of public administration [Sistema marketingovih komunikacij $\mathrm{v}$ mehanizmah derzhavnogo upravlinnja]. Actual problems of economy - Aktual'ni problemi ekonomiki, 12 (186), 81-89. 